\title{
CORRECTION
}

\section{Correction to: An investigation of the impact of MVA normalization on the advanced front-end features}

\author{
Azzedine Touazi $^{1,2} \cdot$ Mohamed Debyeche $^{2}$
}

Published online: 29 November 2018

(c) Springer Science+Business Media, LLC, part of Springer Nature 2018

\section{Correction to: International Journal of Speech Technology https://doi.org/10.1007/s10772-018-09561-x}

The authors regret that the term "intra-frame" should be corrected. Throughout the entire paper, the term "intra-frame" should be replaced by the term "inter-frame".

The original article can be found online at https://doi.org/10.1007/ s10772-018-09561-x.

Azzedine Touazi

touazi.azzedine@gmail.com

Mohamed Debyeche

mdebyeche@gmail.com

1 Center for Development of Advanced Technologies (CDTA), Algiers, Algeria

2 University of Science and Technology Houari Boumediene (USTHB), Algiers, Algeria 